\title{
INTRODUCTION
}

The aim of this catalogue is to bring to the attention of scholars and the general public an exceptional collection of cylinder seals. This introduction has been written for members of the public not familiar with the field of ancient Near Eastern glyptic art in the bope that it will answer some of the questions the subject may arouse.

The appearance of cylindrically shaped seals in the second half of the fourth millennium B.c. in southern Iraq and southwestern Iran revolutionized the seal cutter's art in the Near East. Until then seals, like conventional seals in more modern times, were stamped to make an impression (stamp seals). The cylindrical shape was not only better suited than that of the stamp to the functional role of covering surfaces with a continuous design, since it might be rolled along the surface to be sealed, but it offered greater surface space on which a frieze of figures or a pattern might be developed.

By the beginning of the third millennium in Mesopotamia, the cylinder seal had virtually replaced the stamp seal; it was to remain the dominant shape there until the later part of the Neo-Assyrian period in the middle of the first millennium when the stamp seal came back into common use. In other regions of the Near East, notably Syria and western Iran, cylinder seals were adopted, but in Anatolia the stamp seal persisted, often in very individual shapes. In the Levant, the stamp seal reappeared in the late second millennium, perhaps influenced by Egyptian scarab seals and Anatolian stamp seals.

\section{ORIGIN AND INITIAL DEVELOPMENT}

No decisive evidence exists at present to explain the change to a cylindrical form; even though the earliest impressions found thus far demonstrate 
functional usage, it is not yet clear whether the form was purposefully developed for functional reasons ${ }^{1}$ or whether it arose as a by-product of another tradition.

Even though the craft of cutting in reverse, known as intaglio, had been developed by stamp seal cutters, the discrepancy both in style and iconography between the scenes on stamp seals and the scenes on the first cylinder seals from Iraq and Iran suggests that the latter rose out of a different cutting tradition, perhaps akin to stone vessel making or sculpture in relief. The appearance of the cylinder seal was roughly contemporary with a renewed fashion for stone vessels. The use of the drill, which is apparent on the earliest cylinder seal impressions found to date as well as in the manufacture of these stone vessels, is indicative of the same technological tradition. ${ }^{2}$ Even if, alternatively, stone cores drilled from stone vessels during their manufacture were used as cylinder seal blanks, the link between cylinder seal carving and the tradition of stoneworking remains. ${ }^{3}$

Certainly the sophisticated designs of the first impressions suggest a prior development. One problem is that no cylinders of the type which produced the first impressions have yet been found. The stones may have been recut and reused, or the first cylinders may have been made of perishable materials such as wood. ${ }^{4}$

\section{USAGE}

The first cylinder seal impressions from Uruk in modern Iraq and Susa in Iran are found on bullae, clay cases that contained counting devices; clay jar stoppers; and clay tablets prior to inscription. Clay covering the ropes used for securing doors to storage areas may also have been sealed.

Sealing ensured the security of goods and authenticated documents. This legal aspect of sealing became one of its primary uses; in conjunction with the owner's name, the impression identified the user of the seal and thus acquired the value of a signature. Sealing practices changed with time and occasionally varied within regions at one time. ${ }^{5}$ From the end of the third millennium, letters and administrative and legal texts were the most common sealed documents, thus tablets and their envelopes are one of the largest groups of clay objects which bear seal impressions.

\section{SEAL TYPES}

Seal types can be broadly divided into three categories: personal seals, official or state seals, and votive or temple seals. Of these by far the largest group are personal seals. 
PERSONAL

In the Ur III period there appear to have been no restrictions regarding the ownership of a seal: anyone who could afford one could own one, or more if so desired. ${ }^{6}$ This probably applies to other periods as well. Seals belonging to women exist, but are comparatively rare. ${ }^{7}$ Seals of high quality could be personally commissioned and were occasionally given as a present from a ruler to his subject. ${ }^{8}$ The loss of a seal was taken seriously. Texts from the Ur III and Old Babylonian periods, for example, record the name of the owner, the year, month, and day when the loss was thought to have been incurred. 9 This procedure protected the owner from subsequent illegal usage of the seal. Losing a seal was also considered to be a bad omen; this added dimension of the significance of a seal will be referred to below.

\section{OFFICIAL}

Official and state seals, including personal royal seals, naturally had a more formal and wider range of uses than a commoner's personal seal. Early and rare examples of official seals are the collective seals from Ur and Jamdat Nasr, on which some of the pictographs standing for various Sumerian cities repeatedly occur in pairs along with scenes of human activity and symbols. ${ }^{10}$ Although the economic and political significance of these seals is still not fully understood, they are thought to provide tangible evidence for a close commercial relationship or alliance between various Sumerian cities. ${ }^{11}$

In the second millennium, royal seals, described in texts as "inimitable" and "incontestable," were invested with special authority and put questions of ownership and of legality beyond dispute. ${ }^{12}$ In Syria, at Ugarit and at Alalakh for example, dynastic seals, that is seals which sometimes carried the genealogy of the ruler and which were handed down from generation to generation, confirmed the lineage of the ruler and his right to the throne. ${ }^{13}$ One example of the degree to which a royal seal was valued is demonstrated by a Neo-Assyrian text in which Sennacherib describes how he found a seal belonging to Tukulti-Ninurta I (c. 1244-1208 B.c.) in the treasurehouse of Merodach-Baladan of Babylon in the late eighth or early seventh century B.C. ${ }^{14}$ This particular seal had thus been preserved for over five hundred years.

TEMPLE

The finer votive seals, or seals that were offered by a king to a god in the temple, were considered property of the temple or, more specifically, of 
XXiv INTRODUCTION

the deity. As with all votive offerings, the gift was intended to help bring health and prosperity to the king and his family. As gifts they were also objects of beauty and ornamentation and were usually intended to be hung around the statue's neck. A number of these seals are not only very largethe seal given to Marduk by Esarhaddon, for example, was $12 \mathrm{~cm}$ high and 4 $\mathrm{cm}$ in diameter-but were carved in relief as opposed to intaglio. ${ }^{15}$ These were still termed kunukku (seal) in Akkadian, although the carving technique places the object in the realm of relief. There is also evidence that such seals could be used in transactions: documents bear impressions of seals belonging to divinities, but these are rare, and in temple transactions a temple official usually used his seal. ${ }^{16}$

\section{THE SEAL CUTTER}

Disappointingly few details are known about the seal cutter's status or the running of his workshop. The Akkadian term for seal cutter is purkullu, although this was a comparatively late, Old Babylonian, term. Purkullu, derived from the Sumerian bur-gul, is equated or associated with zadim in lexical lists. ${ }^{17}$ The zadim was a lapidary or stoneworker, an artisan who was part of a professional group. A text from the Ur III period records the activities of certain craftsmen, including the zadim, during one year. All existed within one establishment that specialized in the production of luxury goods. The section dealing with the zadim lists stones supplied to the workshop and implies that the zadim may have been involved in work other than cutting, shaping, and polishing them, for instance, the making of composition materials, such as frit. ${ }^{18}$

At Alalakh there is evidence to suggest that, in the second half of the second millennium, the seal cutter belonged to a particular social class which consisted of high-ranking private citizens often employed by the palace. ${ }^{19}$ A very much later reference to a seal cutter, dating from the Achaemenid period, states that a slave was apprenticed for four years to learn the craft of the purkullu. ${ }^{20}$ There is also a reference to the seal cutter's house at Alalakh, suggesting that he was resident and not itinerant. ${ }^{21}$

At other times the seal cutter appears to have had a particularly close relationship with the palace. For example, Akkadian seals showing mostly presentation and combat scenes are thought to belong to a specifically court tradition. ${ }^{22}$ In earlier periods, however, and for most of the Early Dynastic period, artistic craftsmanship seems to have been associated with the temple. ${ }^{23}$ 
INTRODUCTION $\quad \mathrm{XXV}$

\section{TECHNOLOGY}

Stone tools, hafted micro- and macroliths and drills, ${ }^{24}$ were probably used in the earlier periods by the engraver, later to be replaced by copper ones such as have been found in a private house at Tell Asmar dating to the Akkadian period. ${ }^{25}$ An Egyptian wall painting from the Fifth Dynasty (c. 2500 B.c.) shows a craftsman drilling a seal with a hand drill. ${ }^{26}$ The bow drill (a drill propelled by a bow), shown on a wall painting from Dynasty VI in the hands of a craftsman making a stone vessel and on a later Dynasty XVIII wall painting for bead making, is, however, thought to have been one of the standard tools of the seal cutter. ${ }^{27}$

The hand drill may have been used in the early stages of manufacture (e.g., to make the bore hole) with the help of an abrasive, such as sand or emery, to create a cavity into which the bow drill would fit. ${ }^{28}$ The examination by scanning electron microscope of silicone rubber impressions of the bore holes of cylinder seals shows that wooden drills could also have been used in Mesopotamia. ${ }^{29}$ The bore holes of both cylinders and beads are usually biconical, thus were drilled from both ends. ${ }^{30}$

Examinations of silicone rubber impressions of the engraved surface of Jamdat Nasr and Proto-Elamite seals have revealed symmetrical tool marks that are characteristic of a rotating disc, probably driven by a horizontal spindle. ${ }^{31}$ The cutting disc again became popular in the second millennium, toward the end of the Old Babylonian period, and remained so. A hollow, tubular drill, used for making circular incisions, was a tool favored by the Mitannian and Syro-Mitannian seal cutters.

The method of polishing seals and beads has still not been established. For beads, tumbling has been suggested. ${ }^{32}$

Some interesting limestone fragments found with other objects belonging to a seal cutter at Ur appear to be trial pieces. On these the seal cutter sketched and engraved figures before beginning work on the actual seal. ${ }^{33}$

A study of the stones of a large assemblage of cylinder seals has shown that softer stones such as marble, limestone, and steatite ( 1 to 3 on the Mohs scale) were more common in the earlier periods, and that hard stones such as hematite were less common until the Old Babylonian period. A valuable material such as lapis lazuli was always relatively rare, and ivory was extremely rare. From the Kassite and Middle Assyrian periods until the Sasannian period, hard stones ( 7 on the Mohs scale) such as quartz and cryptocrystalline materials became more frequently used. ${ }^{34}$ A glance at the chart of materials (Appendix B) in this collection substantiates this finding. The survey did not include seals made from composition materials.

Composition materials with a glazed surface were frequently used for seals of the Mitannian Common style; they were also used more spo- 
radically for Neo-Assyrian seals in the first millennium. Glass seals were characteristic of Middle Elamite glyptic workshops.

\section{MOUNTING AND WEARING}

The manner in which seals adorned the statues of deities has been mentioned above. A person usually carried his seal strung as the central bead of a necklace or mounted in gold with a little loop, attached to a necklace. It could also be mounted on a pin. Figures on an Early Dynastic mosaic panel and other small figures originally from an inlay from Mari wear their seals hanging from a small chain attached to a pin. ${ }^{35}$ The mountings of seals, often of gold, varied from simple to elaborate caps decorated with the granulation distinctive of the Kassite period. ${ }^{36}$

\section{INSCRIPTIONS}

A significant number of seals are inscribed. Although a preliminary typology of these inscriptions ${ }^{37}$ distinguishes thirty-one main types, only the most common will be mentioned here.

Probably the most frequently found type of inscription includes the owner's name often followed by his father's name. Personal names first appear on seals in the Early Dynastic period, and the custom became widespread in the Akkadian period. At this period inscriptions with a personal name and the owner's profession or title were equally common. Another type of inscription common in the Old Babylonian period was one in which the owner was described as being the servant (Akk. arād [m.], gemē [f.]) of a given deity (see, e.g., seals 126 and 127) or of another professional person or ruler.

Inscriptions that gave only the name or names of a deity (e.g., seals 107 and 121) are also fairly common. Seals with short prayer inscriptions, a late Old Babylonian and Kassite feature, are unusual. Similarly, extracts of incantations occur only on Kassite seals. ${ }^{38}$ More exceptional are those inscriptions on seals such as the dynastic seals mentioned above which sometimes give genealogy, and those on special votive seals which are unusually lengthy and varied.

The relationship between inscription and iconographical representation will be referred to below. 
INTRODUCTION $\quad$ XXVii

\section{SEALS AS AMULETS}

There are indications in medical, ritual, and omen texts that seals sometimes had an amuletic value. It is not known whether these seals, also referred to as kunukku, should be regarded as a particular type. An incantation text against slander describes how a seal was rolled on clay tongues (to silence them) which were then enclosed and sealed in a clay boat which was then thrown into the river. ${ }^{39}$ Similarly, in an incantation text from the maqlû series which deals with warding off enemies, a seal is rolled across a clay figurine to seal its lips. ${ }^{40}$

In a medical text pertaining to childbirth, seals are placed on parts of the body to prevent the woman from losing her baby. ${ }^{41}$

The type of stone used for the seals in these rituals is often specified: the baltu stone (ZA.SUH, translated as vitriol-stained stone), ${ }^{42}$ the šubu stone (agate?), ${ }^{43}$ and the šadanu stone (hematite) ${ }^{44}$ appear to have been favored. A medical text and an omen text pertaining to dreams list the different portents of different stones. ${ }^{45}$ A seal of marble portended favors, a seal of $d u s ̌ u$ stone ${ }^{46}$ (a precious stone of a yellow-orange color) portended profits.

The predictions of the different texts occasionally contradict each other; in one text a seal of marble brings favors, in the other the person "will not attain his heart's desire." 47 The propitious nature of lapis lazuli, however, appears to have been universally accepted.

Omens concerning inscribed seals also exist, but unfortunately most of the essential passages are broken. ${ }^{48}$ The same text also lists, for example, the portent of a seal with figures on it, which would bring the person sons or peace of mind, or of a royal seal, which signified divine protection. ${ }^{49}$

Although it appears that some seals could be used as amulets and some were inscribed with incantations, the evidence for usage in magic is comparatively slender and does not allow one to conclude that all seals had an amuletic as well as a more practical significance for the owner.

This view is contested by some scholars, notably Edith Porada, who believes that cylinder seals were as much amuletic as "an integral part of their owners' persons." 50

\section{ICONOGRAPHY}

As will become apparent in the following chapters, ironclad interpretation of the various scenes represented on the seals and identification of the various figures are often not possible. The identification of deities by their 
XXviii INTRODUCTION

particular iconography, although standard practice, is not always accepted. ${ }^{51}$ There is enough general uniformity, particularly in the representation of major deities, to suggest that the seal cutters worked with a standard iconography. ${ }^{52}$ Different workshops naturally had idiosyncracies, but these are generally stylistic. The identification of various figures is complicated in some iconographical repertoires, such as the Syrian one, by the eclecticism of the iconography. It has also been suggested that some seals that show originality of representation may have been made by nonprofessionals for specific rituals. ${ }^{53}$ Seals that show unusual scenes, such as scenes of exorcism, for example, 232, may also have been made to be used in certain medicinal or magical rites. ${ }^{54}$

Inscriptions on seals by no means guarantee the identification of figures: on a great number of seals one deity is named in the inscription and another is depicted on the seal (e.g., 121). On certain commissioned seals (e.g., the seal of Daguna, a wet nurse, which shows a figure being introduced to a female deity, probably Ninhursag, whose milk legitimized princes) 55 and on certain official seals (the seal of Sennacherib, which shows Ashur and his consort Ninlil with the figure of a king between them), ${ }^{56}$ a relationship between the inscription and the figures depicted can nevertheless be found.

The use of mythological and ritual texts for the interpretation of scenes on seals, notably from the Akkadian period, was pioneered by Henri Frankfort. He believed that certain myths found pictorial expression in differing renditions on a number of seals, and found various parallels from late texts to substantiate this claim (see chapter three). ${ }^{57}$

The interpretation of the intrinsic meaning of a scene (iconology) has occasionally been attempted. Amiet, for example, sees in the Akkadian repertoire an illustration of universal mythological concepts. ${ }^{58}$ This is an intuitive approach which does not suit all scholars. ${ }^{59}$

Cylinder seals may be thought to belong to a minor art form. However, "if one considers only the size of an art object, such as a cylinder seal, it may seem appropriate to call it minor, but size is not a criterion of aesthetic value. A piece of jewelry or a cylinder seal can be more beautiful than a monumental sculpture. Aesthetically a seal is unique. It can be beautiful in itself, as a stone; and it can be beautiful in the pictorial impression it makes. In those civilizations where it is the primary source of images it becomes a major pictorial art form, the equivalent of frescoes and paintings in another culture. Nevertheless, the scope for pictorial development in a seal is not comparable with that of a painting; but what the seal lacks in scope, it may gain in intensity, impact, clarity of design and coherence." 60 